\title{
Long-term silver effects on the marine gastropod Crepidula fornicata
}

\author{
D. A. Nelson ${ }^{1}$, A. Calabrese ${ }^{1}$, R. A. Greig ${ }^{1}$, P. P. Yevich ${ }^{2}$ and S. Chang ${ }^{3}$ \\ ${ }^{1}$ National Marine Fisheries Service, Northeast Fisheries Center, Milford Laboratory, Milford, Connecticut 06460, USA \\ ${ }^{2}$ US Environmental Protection Agency, Environmental Research Laboratory, Narragansett, Rhode Island 02882, USA \\ ${ }^{3}$ National Marine Fisheries Service, Northeast Fisheries Center, Sandy Hook Laboratory, Highlands, New Jersey 07732 , USA
}

\begin{abstract}
The marine gastropod Crepidula fornicata was exposed for 24 mo to 1,5 , and $10 \mu \mathrm{g} \mathrm{l}^{-1}$ silver as the nitrate. Chronic sublethal exposure of 120 mating pairs demonstrated some effects of silver on reproductive behavior of both a parental stock and an $F_{1}$ generation. At least 5 pairs from each silver-exposed group and control group were observed for egg production and larval release. The number of spawnings per female and number and size of larvae at each release were recorded. Parental C. fornicata exposed to silver for 6, 12, and 24 mo were analyzed for body burdens of silver and copper. $F_{1}$ C. fornicata exposed for 24 mo were analyzed similarly. Larval releases in the parental stock of $C$. fornicata were significantly reduced in the $10 \mu \mathrm{g} \mathrm{l}^{-1}$ silver-exposure group. The average number of larvae at each release of the parental stock was higher in the $1 \mu \mathrm{g} \mathrm{l}^{-1}$ group than either the controls or other exposure groups, while larval size was similar for all groups. In the $F_{1}$ generation, the number of larvae released was lower in the $5 \mu \mathrm{g}^{-1}$ group than in the controls. Parental $C$. fornicata accumulated significant amounts of silver over the 24 -mo test period. At $24 \mathrm{mo}$, however, there was a significant reduction in silver from the 12 -mo samples. Copper was also accunulated to high levels, with silverexposed individuals accumulating significantly greater amounts than controls. The $F_{1}$ generation accumulated high levels of both silver and copper. Histopathologic examination of parental $C$. fornicata exposed to 1,5, and $10 \mu \mathrm{g} \mathrm{l}^{-1} \mathrm{Ag}$ for $24 \mathrm{mo}$ showed deposition and retention of silver in the connective tissue and basement membrane of various tissues and organs.
\end{abstract}

\section{INTRODUCTION}

Silver is a metal that has received relatively little attention in aquatic toxicity studies, particularly in the marine environment. Although it is not generally assumed to be a widespread pollutant, it does occur in industrial discharges and should be listed in any classification of highly toxic, potential pollutants (Bowen, 1966; Saila and Segar, 1979). Schutz and Turekian (1965) measured silver levels as high as $19.6 \mu \mathrm{g}^{-1}$ in water samples collected from Long Island Sound at the mouth of the Housatonic River, near Milford, Connecticut, USA. Greig et al. (1977) reported sediment levels of silver ranging from $6.7 \mu \mathrm{g} \mathrm{g}^{-1}$ (dry weight) to nondetectable limits $\left(<0.3 \mu \mathrm{g} \mathrm{g}^{-1}\right)$ in Long Island Sound, with the greatest concentrations found at the western end of the Sound. Greig et al. (1975) measured levels of silver as high as $12.1( \pm 4.5) \mu \mathrm{g} \mathrm{g}^{-1}$ (dry wt) in American oysters Crassostrea virginica from the Housatonic River and Greig (1975) reported silver levels of $30 \mu \mathrm{g}$ $\mathrm{g}^{-1}$ (wet wt) in digestive diverticula of the channeled whelk Busycon canaliculatum from Long Island Sound.

In acute toxicity studies with embryos of Crassostrea virginica, Calabrese et al. (1973) found the toxicity of silver to be similar to that of mercury, i.e. the $\mathrm{LC}_{50}$ values for survival were 5.8 and $5.6 \mu \mathrm{g} \mathrm{l}^{-1}$, respectively. Calabrese and Nelson (1974) reported the $\mathrm{LC}_{50}$ value for embryos of the hard clam Mercenaria mercenaria exposed to silver to be $21.0 \mu \mathrm{g} \mathrm{l}^{-1}$. Larvae of the marine gastropod Crepidula fornicata exposed to silver for $12 \mathrm{~d}$ had an $\mathrm{LC}_{50}$ value of $22.0 \mu \mathrm{g} \mathrm{l}^{-1}$ (Nelson 1978). These studies provided a further focus for determining the toxic effects of silver on marine organisms (Calabrese et al., 1977; in press).

Silver can be concentrated by marine organisms either directly from the water or through their food Although adult marine animals may not be noticeably affected by a relatively brief exposure to low levels of silver, long-term exposure (a year or more) might eventually affect some other stage of their life cycle or their 
offspring. Of the numerous studies of heavy-metal effects on specific life stages of marine animals, few have been devoted to an entire life cycle and to succeeding generations (Nimmo et al., 1977; Reish and Carr, 1978; Tyler-Schroeder, 1979). This is especially true of molluscs. Calabrese et al. (in press) considered those molluscs that would be practical to work with from the standpoint of local abundance, size, sedentariness, short generation time, fecundity, and ease of culture in the laboratory when considering entire lifecycle studies. With the marine snail Crepidula fornicata, as recommended by Calabrese and Rhodes (1974), research could be performed on the sublethal effects of contaminants on viability, growth, and reproduction in succeeding generations. Because of these advantages, Calabrese et al. (in press) studied the sublethal effects of silver to $C$. fornicata held for $12 \mathrm{mo}$ in a chronic exposure system. This report is a continuation of that study, documenting fecundity, larval survival and growth, viability of succeeding generations, and metal uptake after a 24-mo exposure. The parental stock was also examined histopathologically.

\section{MATERIALS AND METHODS}

Adult Crepidula fornicata were collected by dredge from commercial oyster beds in Long Island Sound off Norwalk, Connecticut, USA, and acclimated in the laboratory for $2 \mathrm{wk}$ before experimental use. Mated pairs were then allowed to attach to a $5 \times 10 \mathrm{~cm}$ Plexiglas* plate. Ten plate-attached pairs were suspended by glass hooks in each of twelve $80-1$ glass aquaria filled to $60 \mathrm{l}$ with seawater, which was first passed through 25- and 10- $\mu \mathrm{m}$ nylon filter bags and then through sand. A proportional-diluter apparatus (Mount and Brungs, 1967) controlled the continuous delivery of silver-containing water and control water at a flow rate of $1 \mathrm{l}$ to each tank every $3 \mathrm{~min}$ throughout the test period, providing a flow of $480 \mathrm{ltank}^{-1} \mathrm{~d}^{-1}$ and an estimated $90 \%$ replacement time of $7 \mathrm{~h}$ (Sprague, 1969). Silver nitrate $\left(\mathrm{AgNO}_{3}\right)$ was added at nominal concentrations of 1,5 , or $10 \mu \mathrm{g} \mathrm{l}^{-1} \mathrm{Ag}$ to each of 3 test tanks, with 3 tanks serving as controls. Silver concentrations refer to calculated concentrations of silver ion in solution; background concentrations, which were less than $1 \mu \mathrm{g}^{-1}$, are not included in the results. Weekly measurements were made of silver concentrations in the test water throughout the entire 2 -yr experiment. The actual values of silver concentrations were nearly identical to the nominal values introduced, i.e.

\footnotetext{
- Mention of trade names does not imply endorsement by the National Marine Fisheries Service
}

the average values throughout the experiment were $1.34( \pm .40), 4.97( \pm 1.14)$, and $10.93( \pm 2.39) \mu \mathrm{gl}^{-1}$.

Plexiglas plates with attached Crepidula fornicata were first introduced into the test system on June 20 , 1978, and exposed continuously until June 30, 1980. Water temperatures during this period ranged from $4.5^{\circ}$ to $25.0^{\circ} \mathrm{C}$ and the salinity was $25 \pm 2 \% \mathrm{~S}$. The test animals utilized whatever food was available in the seawater source and were supplementally fed a limited amount of cultured unicellular algae once a week. The mean length of adult females used in this study was $33.6 \mathrm{~mm}$ (range: 28.7 to $41.2 \mathrm{~mm}$ ). After copulation and fertilization, the females produced yellow egg sacs which, by adhering to the Plexiglas plates, allowed observation of the developing larvae. When the egg sacs of individual females appeared brown to gray in color (an indication that larval release was imminent), the Plexiglas plate, with attached mating pair, was transferred to a 3-1 polypropylene container with seawater at the same concentration of silver as the tank from which it was removed, to allow for the release and retention of veliger larvae from a single female. After each individual larval release, the mated pair was returned to its original test tank for further egg production. The number of larval releases for each of 10 females from each test concentration of silver and controls was recorded for the entire test period. The larvae released by each female in the 3-1 containers were mixed to a uniform suspension by gentle aeration and then counted by taking 20 subsamples of $5 \mathrm{ml}$ each, which were then individually counted, averaged, and the average multiplied by a factor of 600 to determine total number of larvae released in the container. Fifteen larvae were then measured to determine their size at release.

$F_{1}$ larvae from each release of a single mating pair of the parental stock at each test concentration and control were held in a 3-1 polypropylene container at the same silver-exposure concentrations as the parents and reared at ambient temperatures $\left(15\right.$ to $\left.25^{\circ} \mathrm{C}\right)$ and $25 \pm 2 \% \mathrm{~S}$ for further experimentation. Each culture was changed daily and fed a mixture of cultured unicellular algae at a rate of approximately 150,000 cells $\mathrm{ml}^{-1}$. The larvae were reared through metamorphosis and the percentage that set was determined. The larvae were set on Plexiglas plates as described above and were suspended and reared as juveniles in 3-1 containers until they grew large enough to be placed in a proportional diluter. After being placed in the diluter, they were maintained at ambient seawater conditions $\left(4.5\right.$ to $25.0^{\circ} \mathrm{C}$ and $25 \pm 2 \%$ S $)$ and at the same silver concentrations in which they were hatched. $F_{1}$ juveniles were then reared to adulthood and a maximum of 10 mated pairs from each release of the single mated pair of parents being followed from 
each test concentration was retained to observe fecundity.

For determination of metal uptake in parental Crepidula fornicata, samples were taken at 6,12 , and 24 mo. Similarly, $F_{1} C$. fornicata were sampled at 24 mo. Both silver and copper concentrations were determined in whole-body soft tissues of animals from each test concentration, with the exception of copper analyses in parents at 1 and $5 \mu \mathrm{g} \mathrm{l}^{-1}$. Analyses for copper were made since background concentrations in the incoming seawater averaged 2 to $4 \mu \mathrm{g} 1^{-1}$. Soft tissues were removed from the shell and digested in nitric acid, followed by small amounts of hydrogen peroxide. The residues were taken up in $5 \%$ nitric acid and analyzed with a Perkin-Elmer HGA 400 graphite furnace on a Perkin-Elmer atomic absorption spectrophotometer (Greig et al., 1982).

Parental Crepidula fornicata exposed to silver for 24 mo were sampled for histopathologic examination. $C$. fornicata were shucked from their shells directly into Helly's fixative. After 10 to $15 \mathrm{~min}$, the snails were removed from the fixative, cut sagittally through the midline and returned to fixative. After overnight fixation (16 to $24 \mathrm{~h}$ ), the C. fornicata were trimmed, washed in running tap water overnight, and processed into slides as described by Yevich and Barszcz (1981).

Metal uptake data were subjected to analysis of variance for determining significant source of variation, and differences between experimental means were compared by the least significant differences (LSD) method. The differences between any 2 means are declared to be significant at the 0.05 level if their uncertainty intervals do not overlap. Uncertainty intervals of means were calculated as LSI $=\bar{y} \pm \mathrm{LSD} / 2$ and graphically presented in interval plots, which are described in detail by Andrews et al. (1980). The number of larval releases was compared using Chisquare, and the differences between controls and means for the number of larvae released, and size and age of $F_{1}$ Crepidula fornicata at first larval release were compared by analysis of variance, multiple comparison, and $t$-tests.

\section{RESULTS}

\section{Life history effects}

After exposure of the parental stock of Crepidula fornicata to silver for 24 mo the number of larvae released was significantly reduced $(P<0.01)$ in the $10 \mu \mathrm{g} \mathrm{l}^{-1}$ Ag exposed group as compared to the controls. There were 92 releases of larvae by 10 females in the control group and 52 releases by 10 females in the $10 \mu \mathrm{g} \mathrm{l}^{-1}$ group. Larval releases in the 1 and $5 \mu \mathrm{g}^{-1}$ groups were 68 and 94, respectively (Table 1). The observed frequencies of the number of abortions were almost evenly proportioned over 4 concentrations. Although the number of abortions ranged only from 24 to 27 , the proportions of abortions over the combined total number of releases and abortions (percent abortions) between concentrations appeared to be different (Table 1). We could not, however, reject the hypothesis of equal proportion between controls and the 3 test concentrations by using arcsine angular transformation for these proportions. For the number of larvae released, the concentration of silver used was a main source of variation ( $P<0.015)$, followed by the biological contributions of individual pairs $(\mathrm{P}<0.02)$. It is not clear why the number of larvae exposed to $1 \mu \mathrm{g} \mathrm{l}^{-1}$ significantly differed $(\mathrm{P}<0.01)$ from controls, whereas results from higher levels of Ag exposure did not. Larval size was similar for each group.

Table 2 shows the size and age at which $F_{1}$ females exposed continuously to silver from egg to adulthood began to spawn. The generation times, from egg to adulthood and first spawning, of females at 1 and $5 \mu \mathrm{g}$ $\mathrm{l}^{-1}$ were significantly different $(\mathrm{P}<0.025)$ from the controls. The age of females exposed to $10 \mu \mathrm{g} \mathrm{l}^{-1}$ was also

Table 1. Crepidula fornicata. Number of larval releases and abortions, and number and size of larvae at release of parental stock exposed to silver for $24 \mathrm{mo}$

\begin{tabular}{|c|c|c|c|c|c|}
\hline $\begin{array}{c}\text { Concentration } \\
\left(\mu \mathrm{g} \mathrm{l}^{-1}\right)\end{array}$ & $\begin{array}{l}\text { Number of } \\
\text { releases (pairs) }\end{array}$ & $\begin{array}{c}\text { Number of } \\
\text { abortions }\end{array}$ & $\frac{\begin{array}{c}\text { Percent abortions } \\
\text { No. abortions }\end{array}}{\text { No. releases }+ \text { abortions }}$ & $\begin{array}{l}\text { Mean number } \\
\text { (range) of larvae } \\
\text { at release }\end{array}$ & $\begin{array}{c}\text { Mean size }(\mu \mathrm{m}) \text { of } \\
\text { larvae at release } \\
\text { (number of releases) }\end{array}$ \\
\hline Controls & $92(10)$ & 26 & $\frac{26}{118}=22.03$ & $5,170 \quad(60-26,550)$ & $393.9(86)$ \\
\hline 1 & $68(10)$ & 27 & $\frac{27}{95}=28.42$ & $7,100(150-25,379)^{\bullet}$ & $399.1(62)$ \\
\hline 5 & $94(10)$ & 26 & $\frac{26}{120}=21.67$ & $5,303 \quad(80-20,220)$ & $401.0(84)$ \\
\hline 10 & $52(10)^{\bullet}$ & 24 & $\frac{24}{76}=31.58$ & $4,874 \quad(400-15,960)$ & 400.4 \\
\hline
\end{tabular}


Table 2. Crepidula fornicata. Mean length (range) and mean age (range) of $F_{1}$ progeny exposed to silver from egg to first larval release

\begin{tabular}{|c|c|c|c|}
\hline $\begin{array}{l}\text { Concentration } \\
\qquad\left(\mu g \mathrm{l}^{-1}\right)\end{array}$ & Number of females & $\begin{array}{l}\text { Mean length in mm } \\
\text { (range) }\end{array}$ & $\begin{array}{l}\text { Mean age in } \mathrm{d} \\
\quad \text { (range) }\end{array}$ \\
\hline Control & 18 & $23.8(19.0-31.0)$ & $300(240-377)$ \\
\hline 1 & 21 & $23.4 \quad(17.5-29.5)$ & $326(260-388)^{\cdots}$ \\
\hline 5 & 19 & $20.4(18.0-26.3)^{\circ}$ & $271(218-240)^{\cdots}$ \\
\hline 10 & 5 & $23.0(20.4-29.5)$ & $235(158-356)^{*}$ \\
\hline \multicolumn{4}{|c|}{$\begin{array}{l}\text { - Significantly different }(\mathrm{P}<.005) \text { from controls } \\
\text { - Significantly different }(\mathrm{P}<0.025) \text { from controls }\end{array}$} \\
\hline
\end{tabular}

Table 3. Crepidula fornicata. Number of larval releases and abortions, and number and size of larvae at release of an $F_{1}$ generation exposed to silver continuously from egg to adulthood

\begin{tabular}{|c|c|c|c|c|c|}
\hline $\begin{array}{c}\text { Concentration } \\
\left(\mu \mathrm{g}^{-1}\right)\end{array}$ & $\begin{array}{l}\text { Number of } \\
\text { releases (pairs) }\end{array}$ & $\begin{array}{l}\text { Number of } \\
\text { abortions }\end{array}$ & $\begin{array}{c}\begin{array}{c}\text { Percent abortions } \\
\text { No. abortions }\end{array} \\
\text { No. releases + abortions }\end{array}$ & $\begin{array}{l}\text { Mean number } \\
\text { (range) of larvae } \\
\text { at release }\end{array}$ & $\begin{array}{l}\text { Mean size }(\mu \mathrm{m}) \text { of } \\
\text { larvae at release } \\
\text { (number of releases) }\end{array}$ \\
\hline Controls & $139(18)$ & 8 & $\frac{8}{147}=5.44$ & $4,721 \quad(90-29,490)$ & $417.6(129)$ \\
\hline 1 & $154(20)$ & 17 & $\frac{17}{171}=9.94$ & $3,992(360-11,100)$ & 406.7 (112) \\
\hline 5 & $97 \quad(13)$ & $38^{\circ}$ & $\frac{38}{135}=28.15^{\circ}$ & $3,044(310-9,900)^{\cdots}$ & $413.5 \quad(51)$ \\
\hline 10 & $36(5)$ & $12^{\circ}$ & $\frac{12}{48}=25.00^{\circ}$ & $4,260(670-13,110)$ & $393.4 \quad(29)$ \\
\hline
\end{tabular}

Table 4. Crepidula fornicata. Percentage of larvae of representative broods of $F_{1}$ progeny exposed to silver at various concentrations that metamorphosed and set, time to setting, and size at setting

\begin{tabular}{|c|c|c|c|c|c|}
\hline Release number & Number of larvae & Number set & Percent set & Time to set (d) & Size $(\mu \mathrm{m})$ \\
\hline \multicolumn{6}{|l|}{ Control } \\
\hline 1 & 6720 & 303 & 4.5 & 21 & 984 \\
\hline 2 & 8460 & 52 & 0.6 & 22 & 1400 \\
\hline 3 & 6110 & 362 & 5.9 & 18 & 1100 \\
\hline 4 & 2580 & 233 & 9.0 & 45 & 1700 \\
\hline \multicolumn{6}{|l|}{$1 \mu \mathrm{g} \mathrm{l^{-1 }}$} \\
\hline 1 & 6300 & 95 & 1.5 & 42 & 1200 \\
\hline 2 & 5340 & 212 & 4.0 & 27 & 1400 \\
\hline \multicolumn{6}{|l|}{$5 \mu \mathrm{g} \mathrm{l}^{-1}$} \\
\hline 1 & 2390 & 129 & 5.4 & 22 & 1500 \\
\hline 2 & 1980 & 77 & 3.9 & 76 & 1800 \\
\hline \multicolumn{6}{|l|}{$10 \mu \mathrm{g} \mathrm{l^{-1 }}$} \\
\hline 1 & 5100 & $30^{\circ}$ & $6.0^{\circ}$ & - & - \\
\hline 2 & 5520 & $3^{\circ}$ & $0.6^{\circ}$ & 32 & 1400 \\
\hline 3 & 4080 & $22^{\circ}$ & $4.4^{\circ}$ & 32 & 1600 \\
\hline
\end{tabular}


Table 5. Crepidula fornicata. Levels $\left(\mu \mathrm{g} \mathrm{g}^{-1}\right.$, wet wt) of silver [mean ( $\pm \mathrm{S}$. D.)] accumulated after 6-, 12-, and 24-mo exposures to silver. Total samples $(T)$; males $(M)$; females $(F)$; number of samples (N)

\begin{tabular}{|c|c|c|c|c|c|c|c|c|c|c|c|c|c|c|c|}
\hline $\begin{array}{l}\text { Exposure } \\
\text { concentration }\end{array}$ & & $0 \mathrm{Mo}$ & $N$ & \multicolumn{3}{|c|}{$6 \mathrm{Mo}$} & $N$ & \multicolumn{3}{|c|}{$12 \mathrm{Mo}$} & \multirow{2}{*}{$\frac{N}{10}$} & \multicolumn{3}{|c|}{$24 \mathrm{Mo}$} & \multirow{2}{*}{$\begin{array}{c}\mathrm{N} \\
14\end{array}$} \\
\hline \multirow[t]{3}{*}{ Control } & $\mathrm{T}$ & $0.84 \quad(0.42)$ & 19 & $\mathrm{~T}$ & 1.09 & $(0.46)$ & 7 & $\mathrm{~T}$ & 2.80 & $(1.20)$ & & $\mathrm{T}$ & 2.22 & $(1.73)$ & \\
\hline & $M$ & $0.79(0.53)$ & 10 & $M$ & 1.00 & $(0.33)$ & 2 & M & 3.72 & (1.24) & 5 & M & 1.52 & $(0.24)$ & 4 \\
\hline & $\mathrm{F}$ & $0.89(0.28)$ & 9 & $\mathrm{~F}$ & 1.13 & $(0.53)$ & 5 & $\mathrm{~F}$ & 2.08 & $(0.19)$ & 5 & $F$ & 2.57 & $(2.05)$ & 10 \\
\hline \multirow[t]{3}{*}{1} & & & & $\mathrm{~T}$ & 16.11 & $(3.86)$ & 9 & $\mathrm{~T}$ & 34.00 & $(18.18)$ & 10 & $\mathrm{~T}$ & 8.02 & $(7.33)$ & 14 \\
\hline & & & & M & 17.67 & $(3.21)$ & 4 & M & 45.72 & $(17.77)$ & 5 & M & 8.66 & $(11.28)$ & 5 \\
\hline & & & & $F$ & 14.87 & $(4.21)$ & 5 & $\mathrm{~F}$ & 22.28 & $(9.20)$ & 5 & $\mathrm{~F}$ & 7.66 & $(4.84)$ & 9 \\
\hline \multirow[t]{3}{*}{5} & & & & $\mathrm{~T}$ & 54.07 & $(22.30)$ & 10 & $\mathrm{~T}$ & 44.90 & $(22.06)$ & 10 & $T$ & 5.36 & $(3.15)$ & 15 \\
\hline & & & & M & 57.20 & (26.49) & 5 & M & 53.82 & (22.11) & 5 & $M$ & 3.60 & $(1.14)$ & 5 \\
\hline & & & & $\mathrm{F}$ & 50.94 & (19.84) & 5 & $F$ & 36.06 & (20.23) & 5 & $\mathrm{~F}$ & 6.23 & $(3.50)$ & 10 \\
\hline \multirow[t]{3}{*}{10} & & & & $\mathrm{~T}$ & 86.71 & $(44.50)$ & 11 & $\mathrm{~T}$ & 70.70 & (69.75) & 10 & $\mathrm{~T}$ & 7.53 & $(3.30)$ & 14 \\
\hline & & & & M & 101.32 & $(62.76)$ & 5 & M & 114.06 & $(74.68)$ & 5 & $M$ & 10.25 & $(4.35)$ & 5 \\
\hline & & & & $\mathrm{F}$ & 74.53 & $(20.30)$ & 6 & $F$ & 27.28 & (25.71) & 5 & $\mathrm{~F}$ & 6.44 & $(2.19)$ & 9 \\
\hline
\end{tabular}

significantly different $(\mathrm{P}<0.005)$ from controls. Females at $5 \mu \mathrm{g} \mathrm{l}^{-1}$ were significantly $(\mathrm{P}<0.005)$ smaller $(20.4 \mathrm{~mm})$ than controls $(23.8 \mathrm{~mm})$ upon first larval release.

The number of larval releases and abortions, and the number and size of larvae released by the $F_{1}$ females from first release and for 18 mo thereafter are shown in Table 3. The number of releases per female at all test concentrations showed no significant differences from controls. The proportion of abortions over the combined total of releases and abortions (or percent abortions) increased with increasing Ag concentrations. The percent of abortions approximately tripled from $1 \mu \mathrm{g} \mathrm{l}^{-1}$ to 5 and $10 \mu \mathrm{g} \mathrm{l^{-1 }}$. Tests using arcsine angular transformation between the control group and the 5 and $10 \mu \mathrm{g} \mathrm{l}^{-1}$ groups were highly significant $(P<0.001)$. The number of larvae released by the $F_{1}$ group also revealed that metal concentration levels were the main source of variation $(P<0.005)$, followed by the factor of biological contribution of individual pairs $(\mathrm{P}<0.025)$. The mean number of larvae released was significantly $(\mathrm{P}<0.025)$ lower in the $5 \mu \mathrm{g} \mathrm{l^{-1 }}$ group compared to the controls. No differences were found in larval size at release for $\mathrm{F}_{1}$ Crepidula fornicata.

The percentage of $F_{1}$ larvae that survived and settled is shown in Table 4. Only a small percentage of the larvae released actually settled and survived. This was true both for control and silver-exposed snails.

\section{Metal uptake}

After 6-, 12-, or 24-mo exposure, the parental stock of Crepidula fornicata accumulated significant $(\mathrm{P}<0.05)$
Fig. 1. Crepidula fornicata. Total concentrations ( $\mu \mathrm{g} \mathrm{g}^{-1}$, wet weight) of silver and copper accumulated by parents (male and female combined) after 6-, 12-, and 24-mo exposures to silver. Bars: uncertainty intervals of means. Means are significantly different $(\mathrm{P}<0.05)$ if intervals do not overlap

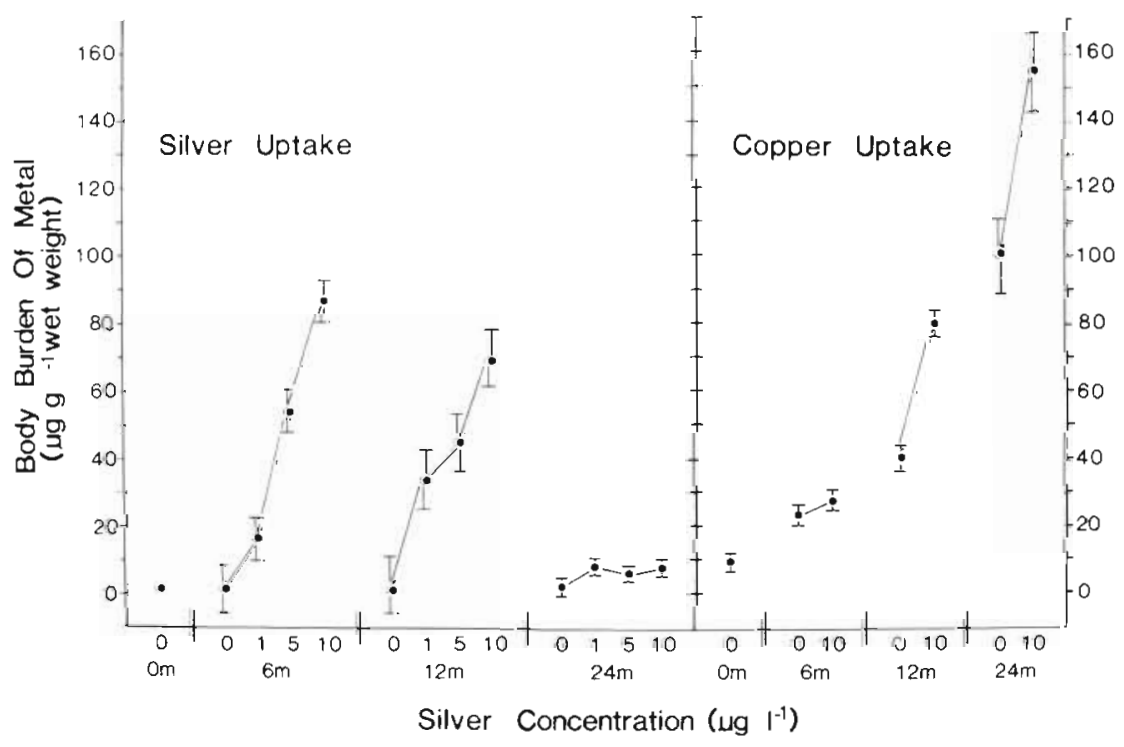




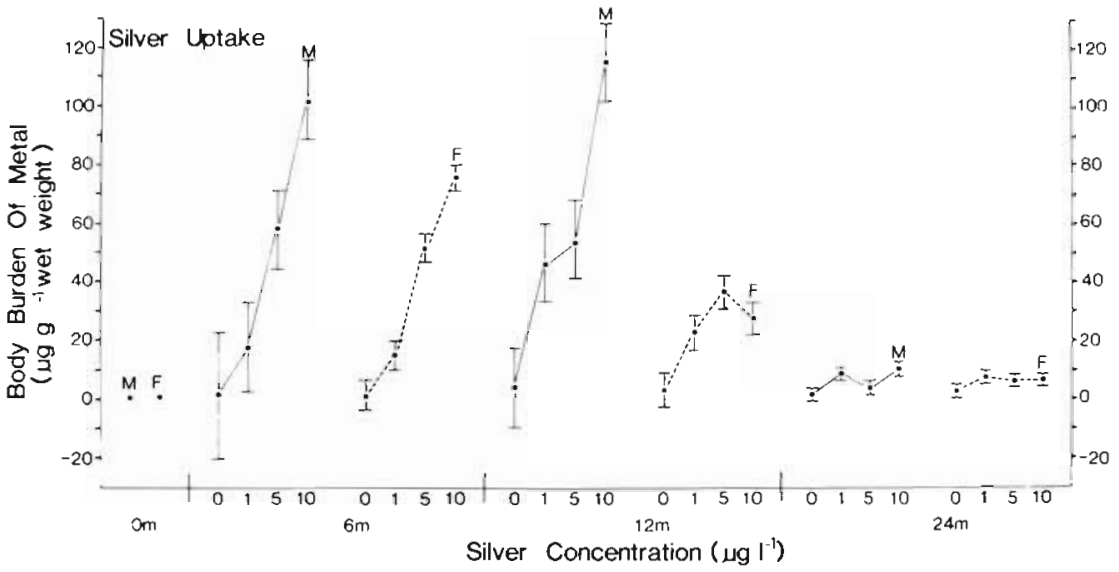

Fig. 2. Crepidula fornicata. Concentrations ( $\mathrm{Kg} \mathrm{g}^{-1}$, wet weight) of silver accumulated by either parental males $(\mathrm{M})$ or females $(\mathrm{F})$ after 6-, 12-, and 24-mo exposures to silver. Bars: uncertainty intervals of means. Means are significantly different $(P<0.05)$ if intervals do not overlap

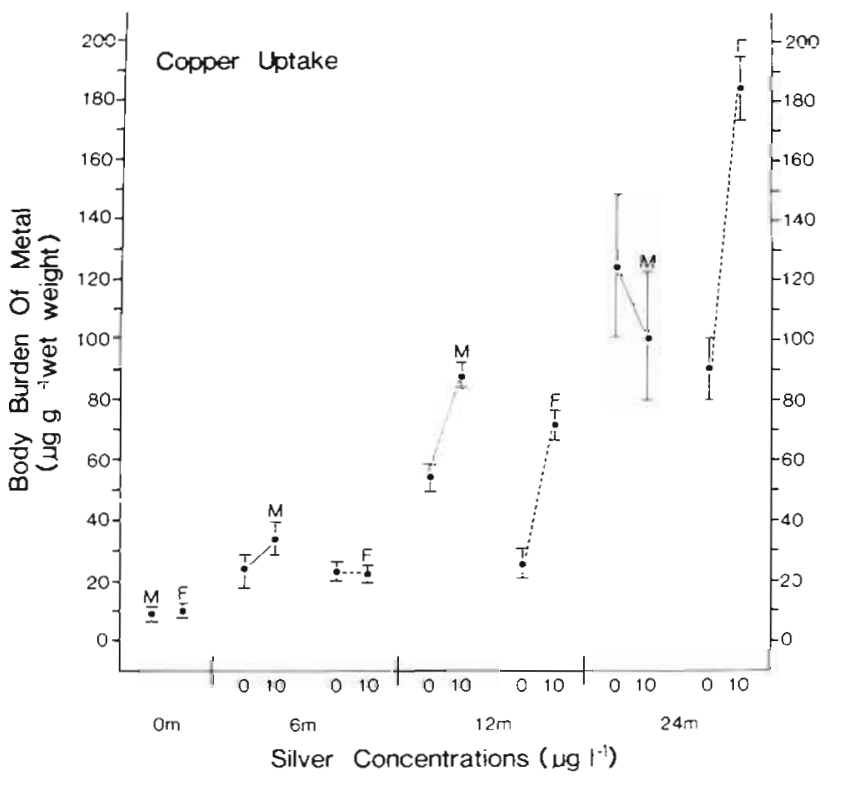

Fig. 3. Crepidula fornicata. Concentrations $\left(\mu \mathrm{g} \mathrm{g} \mathrm{g}^{-1}\right.$, wet weight) of copper accumulated by either parental males (M) or females (F) after 6-, 12-, and 24-mo exposures to silver. Bars: uncertainty intervals of means. Means are significantly different $(\mathrm{P}<0.05)$ if intervals do not overlap amounts of silver in whole-body tissues at all 3 test concentrations (Fig. 1). At 12 mo silver was still being accumulated by the $1 \mu \mathrm{g}^{-1}$ group, whereas no increase was evident between 6 and 12 mo in the 5 and $10 \mu \mathrm{g} \mathrm{I}^{-1}$ groups (Table 5). After 24 mo silver concentrations were significantly reduced (Table 5, Fig. 1). Males at the $10 \mu \mathrm{g} \mathrm{l}^{-1}$ exposure concentration accumulated significantly larger amounts of silver in their tissues than females (Fig. 2). Moreover, there was a significant decrease $(\mathrm{P}<0.05)$ in silver concentrations in tissues of females in the 5 and $10 \mu \mathrm{g} \mathrm{l}^{-1}$ exposure groups from the 6- to 12-mo exposure period and a further significant decrease $(\mathrm{P}<0.05)$ in both males and females at all test concentrations from 12 to 24 mo. For silver accumulation with Ag exposures, the concentration of silver tested was the most significant source of variation, followed by the factors of time and sex. Each factor was significant $(P<0.005)$ for silver accumulation in the tissues of both sexes over the 6-, 12-, and 24-mo exposure periods at 1,5 , and $10 \mu \mathrm{g} \mathrm{l^{-1 }} \mathrm{Ag}$.

In addition to silver analyses in tissues of silverexposed snails, analyses for copper levels were performed on the controls and $10 \mu \mathrm{g} \mathrm{l}^{-1}$ group. As copper in the incoming seawater averaged 2 to $4 \mu \mathrm{g} \mathrm{I}^{-1}$, we were interested in knowing whether uptake of copper

Table 6. Crepidula fornicata. Levels ( $\mu \mathrm{g} \mathrm{g}^{-1}$, wet wt) of copper [mean ( \pm S. D.)] accumulated after 6-, 12-, and 24-mo exposures to silver. Total samples $(T)$; males $(M)$; females $(F)$ i number of samples $(N)$

\begin{tabular}{|c|c|c|c|c|c|c|c|c|c|c|c|c|}
\hline $\begin{array}{c}\text { Ag exposure } \\
\text { concentration } \\
\left(\mu \mathrm{g} \mathrm{l}^{-1}\right)\end{array}$ & & $0 \mathrm{Mo}$ & $\mathrm{N}$ & & $6 \mathrm{Mo}$ & $N$ & & $12 \mathrm{Mo}$ & $N$ & & $24 \mathrm{Mo}$ & $N$ \\
\hline \multirow[t]{3}{*}{ Control } & $\mathrm{T}$ & $9.37(6.15)$ & 19 & $\mathrm{~T}$ & $23.11 \quad(9.43)$ & 7 & $\mathrm{~T}$ & $39.93(18.1)$ & 10 & $\mathrm{~T}$ & $100.05(44.23)$ & 14 \\
\hline & M & $8.88(6.01)$ & 10 & M & $23.12(12.24)$ & 2 & $M$ & $54.14(14.1)$ & 5 & $M$ & $124.33(48.35)$ & 4 \\
\hline & $\mathrm{F}$ & $9.91(6.61)$ & 9 & $\mathrm{~F}$ & $23.10 \quad(7.08)$ & 5 & $F$ & $25.72 \quad(5.5)$ & 5 & $\mathrm{~F}$ & $90.33(40.99)$ & 10 \\
\hline \multirow[t]{3}{*}{10} & & & & $\mathrm{~T}$ & $27.56(14.85)$ & 11 & $\mathrm{~T}$ & $79.55(16.1)$ & 10 & $T$ & $154.52(61.00)$ & 14 \\
\hline & & & & M & $34.00(18.22)$ & 5 & $M$ & $87.74 \quad(9.8)$ & 5 & M & $101.24(30.19)$ & 5 \\
\hline & & & & $\mathrm{F}$ & $22.17 \quad(9.94)$ & 6 & $\mathrm{~F}$ & $71.36(17.8)$ & 5 & $F$ & $184.12(53.21)$ & 9 \\
\hline
\end{tabular}


would occur. Copper was accumulated by control snails from a concentration of $9.37 \mu \mathrm{g} \mathrm{g}^{-1}$ (wet wt) at the start of the experiment to a concentration of $100.05 \mu \mathrm{g}$ $\mathrm{g}^{-1}$ (wet wt) over the 24-mo test period (Table 6). For copper accumulation with silver exposures, the duration of exposure was the most dominant factor $(P<0.005)$, followed by the concentration of silver tested. Sex, apparently, did not influence copper accumulation. There was no difference in copper uptake between the controls and $10 \mu \mathrm{g} \mathrm{l} \mathrm{l}^{-1}$ exposure group for either sex after $6 \mathrm{mo}$; however, at 12 and 24 mo, copper was significantly higher in the $10 \mu \mathrm{g} \mathrm{l}^{-1} \mathrm{Ag}$ exposed group than in the controls (Fig. 1). Although there were significant differences in uptake of copper by males and females, no particular pattern of uptake occurred in either sex (Table 6, Fig. 3).

Table 7. Crepidula fornicata. Levels $\left(\mu \mathrm{g} \mathrm{g}^{-1}\right.$, wet wt) of silver and copper [mean ( \pm S. D.)] accumulated by $F_{1}$ progeny after 24-mo exposure to silver. Total samples (T); males (M); females $(F)$; number of samples $(\mathrm{N})$

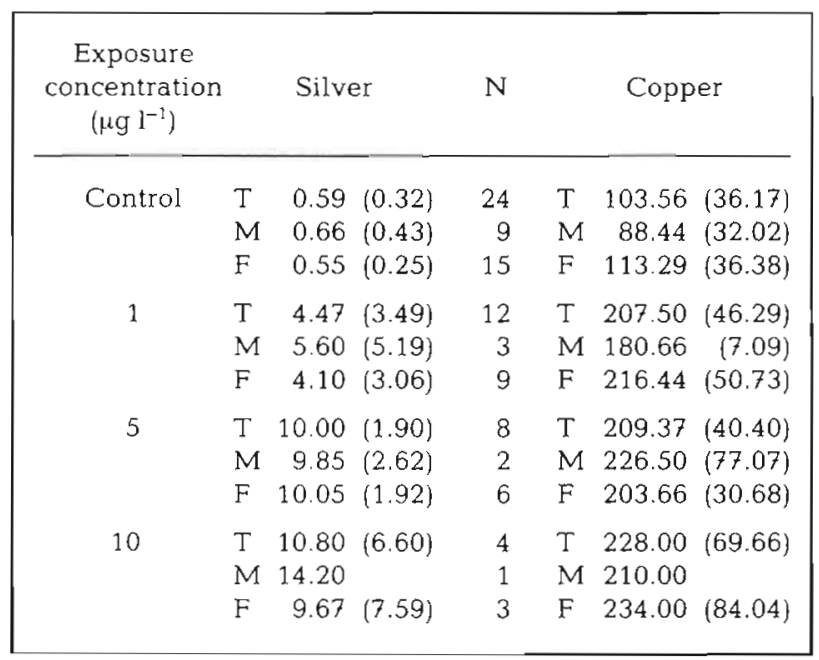

Whole-body analyses for silver and copper were performed on the $F_{1}$ generation of Crepidula fornicata exposed to silver from hatching to $24 \mathrm{mo}$ of age. Significant concentrations $(P<0.05)$ of silver were accumulated by $C$. fornicata at all 3 test concentrations with more silver being accumulated at the 5 and $10 \mu \mathrm{g}$ $\mathrm{l}^{-1}$ exposure levels than at $1 \mu \mathrm{g} \mathrm{l}^{-1}$ (Table 7. Fig. 4). Copper was also accumulated from the ambient seawater by both control and exposed snails, but with significantly higher concentrations $(\mathrm{P}<0.05)$ accumulated by the silver-exposed groups (Fig. 4). No particular pattern in uptake of either silver or copper was observed for either sex.

\section{Histopathology}

The histopathologic examination of parental Crepidula fornicata exposed to 1,5 , and $10 \mu \mathrm{g} \mathrm{l}^{-1} \mathrm{Ag}$ for 24 mo showed deposition and retention of silver in the connective tissues and basement membranes of the various tissues and organs. The greater accumulation of silver especially noted in the 5 and $10 \mu \mathrm{g} \mathrm{l}^{-1} \mathrm{Ag}$ exposed individuals tends to cause a condition of silver poisoning called argyria.

At $1 \mu \mathrm{g} \mathrm{l^{-1 }}$ all snails showed the basement membrane and connective tissue of the digestive gland and stomach to contain numerous brown and black granules. At low magnification the digestive gland appeared to be outlined by a black band (Figs. 5,6 ).

At $5 \mu \mathrm{g} \mathrm{l}^{-1}$ all snails revealed much the same picture as those at $1 \mu \mathrm{g} \mathrm{l}^{-1}$; however, the band of black was much more intense in color and wider in width and also the basement membrane and connective tissue of the intestine were involved. The connective tissue of the visceral mass, kidney, heart, gills, reproductive tract, and basement membrane of the epithelium of the
Fig. 4. Crepidula fornicata. Concentrations ( $\mu \mathrm{g} \mathrm{g}^{-1}$, wet weight) of silver and copper accumulated by $F_{1}$ progeny after 24-mo exposure to silver. Total ( $T$ ); males $(\mathrm{M})$; females $(\mathrm{F})$

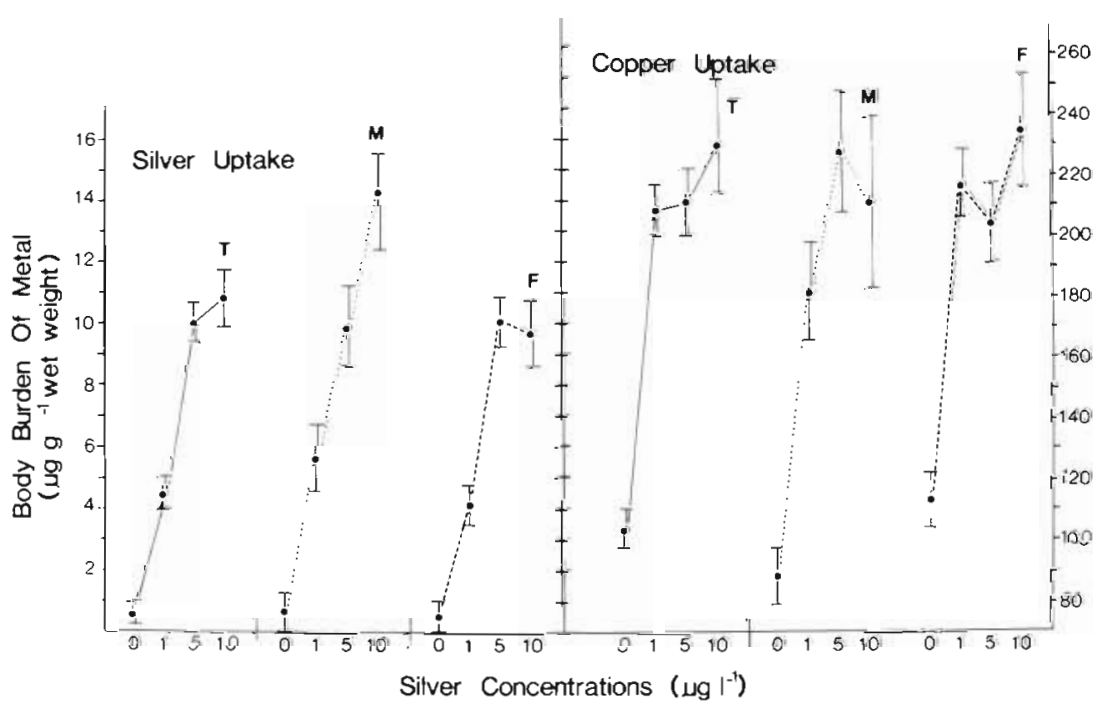



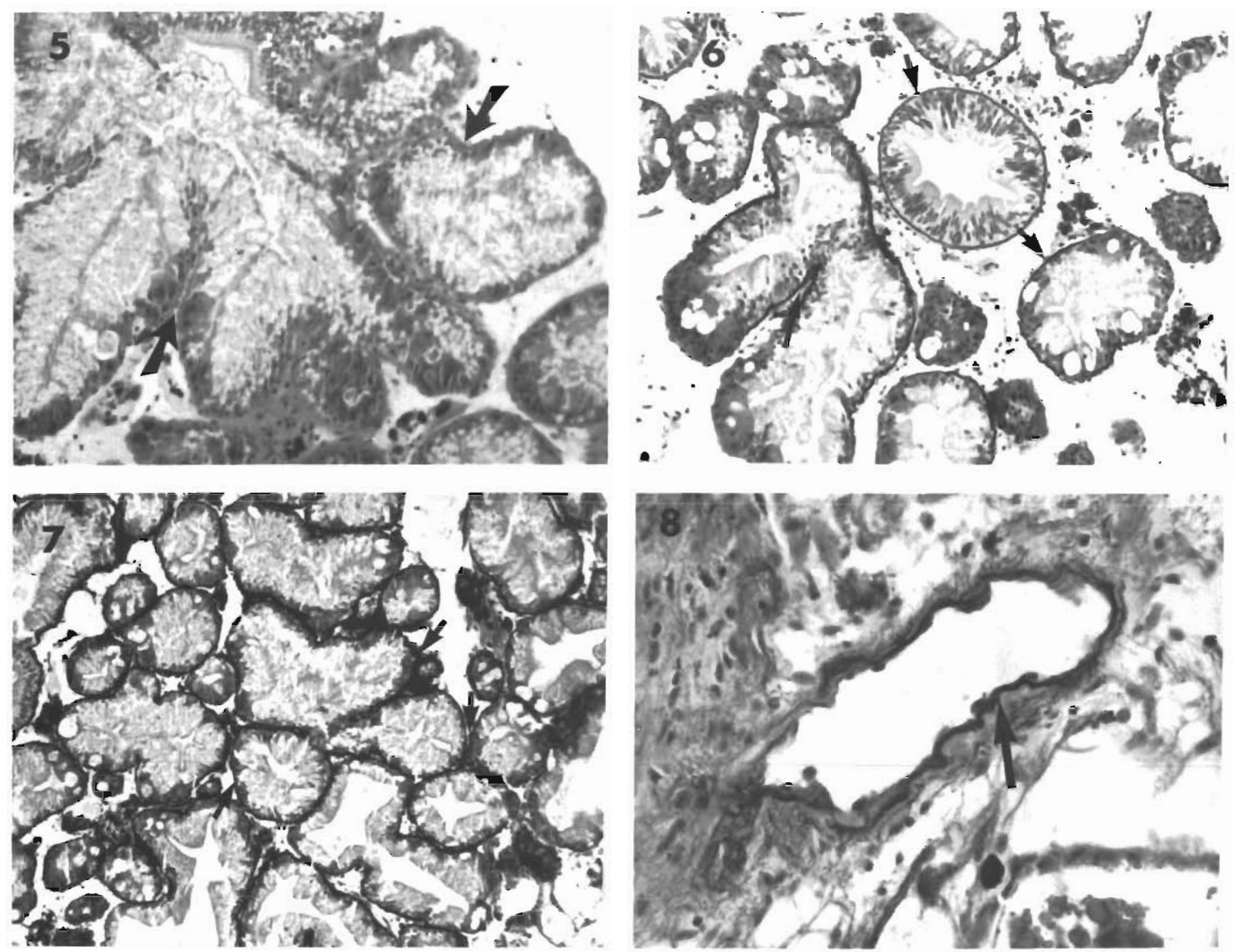

Figs. 5. to 8. Crepidula fornicata. Fig. 5. Tubules of digestive gland of a control. Arrows: normal basement membranes around digestive tubules. Fig. 6. Tubules of digestive gland exposed to $1 \mu \mathrm{g} \mathrm{l} \mathrm{l}^{-1}$ silver. Arrows: silver deposited along basement membranes of ducts and tubules. Fig. 7. Tubules of digestive gland exposed to $10 \mu \mathrm{g} \mathrm{I}{ }^{-1} \mathrm{Ag}$. Arrow: basement membranes with increased amounts of silver deposit. Fig. 8. Blood vessel exposed to $10 \mu \mathrm{gl}^{-1} \mathrm{Ag}$. Arrow: silver deposited in connective tissue of blood vessel wall. All figures $25 X$ H \& E

body walls showed brownish to black particulate in the cytoplasm. Even the fibrotic tissue around nematodes was brown to black in color.

The $10 \mu \mathrm{g} \mathrm{l}^{-1}$ exposed snails showed the same picture as the other 2 exposure groups; however, the black bands around the stomach, digestive gland, blood vessels, and intestine were wider and more dense (Figs. 7 , 8), and the amount of brownish to black particulate in the connective tissue and basement membrane was wider and more dense. It appeared as though all the connective tissue and basement membrane of the body were brownish to black in color.

\section{DISCUSSION}

The purpose of this study was to determine what effect long-term exposure to silver might have on reproduction of a parental stock of Crepidula fornicata and any succeeding generations. Larval releases of parental $C$. fornicata were significantly lower $(P<0.01)$ for the $10 \mu \mathrm{g} \mathrm{l}^{-1} \mathrm{Ag}$ exposed snails than for controls (Table 1), whereas no significant differences were noted in the $F_{1}$ population (Table 3). Although the number of releases in $F_{1}$ snails at 5 and $10 \mu \mathrm{g} \mathrm{l}^{-1} \mathrm{Ag}$ appeared to be lower than controls (Table 3), statistical 
treatment of the data indicated no differences. In addition, the number of abortions of eggs in the $F_{1}$ group (i.e. the shedding of brooding eggs before hatching) at both 5 and $10 \mu \mathrm{g} \mathrm{l}^{-1} \mathrm{Ag}$ exposure was higher than either the controls or $1 \mu \mathrm{g} \mathrm{l}^{-1}$ group (Table 3 ).

Bryan and Hummerstone (1977) and Bryan et al. (1977) suggested that gastropod molluscs accumulate more metals from their food than from water. Although this study was not designed to differentiate metal uptake in gastropods by these two methods, it does appear likely that substantial amounts of metals can be accumulated from the water (Tables 5, 6). There were significant increases of both silver and copper in whole-body tissues of parental Crepidula fornicata exposed for 24 mo to silver and for $F_{1}$ individuals exposed for $24 \mathrm{mo}$. Whether these metals were accumulated in part by $C$. fornicata from ingestion of particulate matter with adsorbed metal from the seawater test system itself is not known. The seawater entering the silver-exposure tanks was first filtered through both 25 - and $10-\mu \mathrm{m}$ nylon filter bags and then a bed of sand. Fluorometric measurements of the filtered water indicated a $50 \%$ reduction in fluorescence from ambient levels. This filtration removed the larger phytoplankters, and allowed small quantities of nannoplankton to pass through. This limited food supply, plus the cultured algae that were periodically added to the test tanks, maintained our test snails for $24 \mathrm{mo}$. No attempt was made to ascertain which organs in $C$. fornicata accumulated the highest concentration of metals; analysis of individual tissues would help to determine the manner in which these metals are accumulated. In a similar experiment, using the same exposure system but with no supplemental feeding, Greig (1979) exposed the filter-feeding bivalve molluscs Arctica islandica (ocean quahog), Spisula solidissima (surf clam), and Crassostrea virginica (American oyster) simultaneously to silver, cadmium, and copper at concentration of $10 \mu \mathrm{g}^{-1}$ of each metal for a maximum of $43 \mathrm{~d}$. In this short time span, oysters took up as much as $15.4( \pm 7.2) \mu \mathrm{g} \mathrm{g}{ }^{-1} \mathrm{Ag}$ (wet wt), surf clams attained a concentration of $6.0( \pm 2.7) \mu \mathrm{g} \mathrm{g} \mathrm{g}^{-1}$, and quahogs 3.5 ( \pm 1.9$) \mu \mathrm{g} \mathrm{g}^{-1}$. Thurberg et al. (1975) reported that surf clams exposed to silver for $96 \mathrm{~h}$ accumulated significant amounts of silver in the gills as compared to the whole body minus the gills. In a similar study, Thurberg et al. (1974) exposed the American oyster and hardshell clam Mercenaria mercenaria to 0.5 and $1.0 \mathrm{mg} \mathrm{l}^{-1} \mathrm{Ag}$ for $96 \mathrm{~h}$ and found that significantly more silver accumulated in gill tissues than in the whole body.

Silver was accumulated rapidly by parental Crepidula fornicata during the first 6 mo of exposure to 1 , 5, and $10 \mu \mathrm{g} \mathrm{l}^{-1} \mathrm{Ag}$, but with no additional accumulation after $12 \mathrm{mo}$. After 24 mo there was a significant reduction $(\mathrm{P}<0.05)$ in silver concentrations in all 3 test groups (Table 5, Fig. 1). It is possibly germane to consider this situation in light of the high copper concentration in body tissues at $12 \mathrm{mo}$, significantly higher than in the control individuals (Table 6, Fig. 1). If there were a preferential uptake for copper, in competition with silver, then when the metal-loading capacity of the body tissues approached saturation, the copper rather than additional silver would be accumulated. This is most clearly seen in female C. fornicata: at 6 mo, when copper concentrations had not yet attained higher values than in controls, silver accumulated in the body tissues proportionally with increasing concentrations of silver exposure; but at $12 \mathrm{mo}$, when copper concentrations had significantly increased, the same low tissue concentration of silver was seen at all levels of silver exposurè. At $24 \mathrm{mo}$, silver levels were depressed in both males and females. Although the reasons for the reduction in silver concentrations are not understood at this time, it is possible that high tissue loads of copper depressed silver uptake and retention or served to sequester and excrete higher levels of silver.

In a similar study (unpubl.), the authors noted that blue mussels Mytilus edulis, exposed to silver in the laboratory for $21 \mathrm{mo}$, exhibited a similar preferential uptake for copper in the presence of silver. Similarly, silver concentrations in mussels increased after 12 and 18 mo of exposure to silver with a subsequent reduction at 21 mo. Popham and D'Auria (1982), in a study correlating the effects of seawater concentrations on trace-metal concentrations in tissues of $M$. edulis, suggested that copper concentrations in mussels were partially a function of the concentration of zinc and/or lead in the seawater, i.e. the uptake of zinc and/or lead by the mussels may have facilitated the uptake of copper. This, then, may also be true with silver. Stenner and Nickless (1974), Phillips (1976), and Lobel et al. (1982) have also suggested that metal interactions may occur in $M$, edulis, thereby facilitating or inhibiting metal uptake. It is necessary, therefore, to consider the interactions of pollutants in the environment when attempting to determine their effects on marine organisms.

After 24 mo of exposure, silver concentrations were not as high in the $F_{1}$ generation (Table 7 ) as in the parental stock, but this may have been due both to age and/or size of snails sampled. Copper levels, on the other hand, were significantly higher $(P<0.05)$ in silver-exposed snails than in controls. Again, a preferential uptake for copper in the presence of silver was obvious.

Histopathologic study of the exposed individuals showed that deposition and accumulation of silver by Crepidula fornicata increased as the test concentration 
increased. The condition of accumulation of silver in the tissues of humans called argyria has been noted in numerous cases and always under chronic exposure to silver compounds in occupationally hazardous jobs and after therapeutic use of medicinals containing silver (Shafer et al., 1963).

Although the accumulation was very extensive in the 5 and $10 \mu \mathrm{g}^{-1}$ exposed snails, no lesions were noted. Rosenman et al. (1979) studied humans exposed to various forms of silver compounds and concluded that silver is of a benign nature. Some investigators claim that silver is not toxic because it binds to protein and sulf-hydryl groups which render it enzymatically inactive (Petering, 1976).

Acknowledgements. The authors wish to thank Ms. Laure Devine, Mr. Barry Nawoichik, and Mr. Michael Elliott for their technical assistance throughout this study, Mrs. M. Cox for the art work, and Ms. R. Riccio for final editing and typing of this manuscript.

\section{LITERATURE CITED}

Andrews, H. P., Snee, R. D., Sarner, M. H. (1980). Graphical display of means. Am. Statist. 34: 195-199

Bowen, H. J. M. (1966). Trace elements in biochemistry. Academic Press, New York

Bryan, G. W., Hummerstone, L. G. (1977). Indicators of heavymetal contamination in the Looe Estuary (Cornwall) with particular regard to silver and lead. J. mar. biol. Ass. U.K. 57: 75-92

Bryan, G. W., Potts, G. W., Forster, G. R. (1977). Heavy metals in the gastropod mollusc Haliotis tuberculata (L.). J. mar. biol. Ass. U.K. 57: 379-390

Calabrese, A., Collier, R. S., Nelson, D. A., MacInnes, J. R. (1973). The toxicity of heavy metals to embryos of the American oyster Crassostrea virginica. Mar. Biol, 18: 162-166

Calabrese, A., Gould, E., Thurberg, F. P. (in press). Effects of heavy metals in marine animals of the New York Bight: some laboratory observations. In: Mayer, G. (ed.) Ecological stress and the New York Bight: science and management

Calabrese, A., Nelson, D. A. (1974). Inhibition of embryonic development of the hard clam, Mercenaria mercenaria, by heavy metals. Bull. environ. Contam. Toxicol. 11: 92-97

Calabrese, A., Nelson, D. A., Nelson, W. G., Greig, R. A. (in press). Reproduction and development of larvae of the marine gastropod Crepidula fornicata after long-term exposure to silver. Proc. 14th Pacific Science Congress, Khabarovsk, USSR, 1979

Calabrese, A., Rhodes, E, W. (1974). Culture of Mulinia lateralis and Crepidula fornicata embryos and larvae for studies of pollution effects. Thalassia jugosl. 10(1/2): 89-102

Calabrese, A. Thurberg, F. P., Gould, E. (1977). Effects of cadmium, mercury, and silver on marine organisms. Mar. Fish. Rev. 39: 5-11

Greig, R. A. (1975). Comparison of atomic absorption and neutron activation analyses for the determination of silver, chromium, and zinc in various marine organisms. Analyt. Chem. 47: 1682-1684
Greig, R. A. (1979). Trace metal uptake by three species of molluscs. Bull. environ. Contam. Toxicol. 22: 643-647

Greig, R. A., Nelson, B. A., Nelson, D. A. (1975). Trace metal content in the American oyster. Mar. Pollut. Bull. 6: 72-73

Greig, R. A., Reid, R. N., Wenzloff, D. R. (1977). Trace metal concentrations in sediments from Long Island Sound. Mar. Pollut. Bull. 8: 183-188

Greig, R. A., Sawyer, T. K., Lewis, E. J., Galasso, M. E. (1982). A study of trace metal concentrations in relation to gill color and pathology in the rock crab, Cancer irroratus Say. Arch. Environm. Contam. Toxicol. 11: 539-545

Lobel, P. B., Mogie, P., Wright, D. A., Wu, B. L. (1982). Metal accumulation in four molluscs. Mar. Pollut. Bull. 13: $170-174$

Mount, D. I., Brungs, W. A. (1967). A simplified dosing apparatus for fish toxicology studies. Wat. Res. 1: 21-29

Nelson, W. G. (1978). The effects of mercury, silver and copper on the survival and growth of Crepidula fornicata larvae. M.S. thesis, University of Bridgeport, Bridgeport, Connecticut.

Nimmo, D. R., Bahner, L. H., Rigby, R. A., Sheppard, J. M., Wilson, A. J., Jr. (1977). Mysidopsis bahia: An estuarine species suitable for life-cycle toxicity tests to determine the effects of a pollutant. In: Mayer, F. L., Hamelink, J. L. (eds.) Aquatic toxicology and hazard evaluation. ASTM STP 634, American Society for Testing Materials, p. 109-116

Petering, H. G. (1976). Pharmacology and toxicology of heavy metals: silver. Pharmacol. Ther. (A) 1: 127-130

Phillips, D.J. H. (1976). The common mussel Mytilus edulis as an indicator of pollution by zinc, cadmium, lead and copper. II. Relationship of metals in the mussel to those discharged by industry. Mar. Biol. 38: 71-80

Popham, J. D. D'Auria, J. M. (1982). Effects of season and seawater concentrations on trace metal concentrations in organs of Mytilus edulis. Arch. Environm. Contam. Toxicol. 11: 273-282

Reish, D. J., Carr, R. S. (1978). The effect of heavy metals on the survival, reproduction, development, and life cycles for two species of polychaetous annelids. Mar. Pollut. Bull. 9: $24-27$

Rosenman, K. D., Moss, A., Kon, S. (1979). Argyria: clinical implications of exposure to silver nitrate and silver oxide. J. occup. Med. 21: 430-435

Saila, S. B., Segar, D. A. (1979). Metals subpanel report. In: O'Connor, J. S., Stanford, H. M. (eds.) Chemical pollutants of the New York Bight: priorities for research. U.S. Dept. Commerce, National Oceanic and Atmospheric Administration, Environmental Research Laboratories, Boulder, Colorado, p. 10-19

Schutz, D. F., Turekian, K. K. (1965). The investigation of the geographical and vertical distribution of several trace elements in sea water using neutron activation analysis. Geochim. Cosmochim. Acta 29: 259-313

Shafer, W. G., Hine, M. K., Levy, B. M. (1963). Oral pathology. W. B. Saunders, Philadelphia

Sprague, J. B. (1969). Measurement of pollutant toxicity of fish. I. Bioassay methods for acute toxicity. Wat. Res. 3: 793-821

Stenner, R. D., Nickless, G. (1974). Distribution of some heavy metals in organisms in Hardangerfjord and Skjerstadfjord, Norway. Wat. Air Soil Pollut. 3: 279-291

Thurberg, F. P., Cable, W. D., Dawson, M. A., MacInnes, J. R. Wenzloff, D. R. (1975). Respiratory response of larval, juvenile, and adult surf clams, Spisula solidissima, to silver. In: Cech, J. J., Jr., Bridges, D. W., Horton, D. B. 
(eds.) Respiration of marine organisms. TRIGOM Publications, South Portland, Maine, p. 41-52

Thurberg, F. P., Calabrese, A., Dawson, M. A. (1974). Effects of silver on oxygen consumption of bivalves at various salinities. In: Vernberg, F. J., Vernberg, W. B. (eds.) Pollution and physiology of marine organisms. Academic Press, New York, p. 67-78

Tyler-Schroeder, D. B. (1979). Use of the grass shrimp (Palaemonetes pugio) in a life-cycle toxicity test. In:
Marking, L. L., Kimerle, R. A. (eds.) Aquatic toxicology. ASTM STP 667, American Society for Testing Materials, p. 159-170

Yevich, P. P., Barszcz, C. A. (1981). Preparation of aquatic animals for histopathological examination. In: Manual of biological field and laboratory methods for measuring the quality of surface waters and wastes. Biological Methods Branch, U.S. Environmental Protection Agency, Cincinnati, Ohio

This paper was presented by Dr. R. S. Scheltema; it was accepted for printing on February 10, 1983 